УДК: 101.1(159.964.2)

https://orcid.org/0000-0001-9980-4372

\title{
КОНЦЕПЦІЯ РОЗЩЕПЛЕННЯ СВІДОМОСТІ У ПСИХОАНАЛІЗІ ТА НАСЛІДКИ ЇЇ ЗАСТОСУВАННЯ ДЛЯ СОЦІАЛЬНОГО ПІЗНАННЯ
}

\author{
3.В. Шевченко, кандидат філософських наук, доцент, \\ доцент кафедри філософії та релігієзнавства
}

Черкаського національного університету імені Богдана Хмельницького

Концепиія розщеплення свідомості у психоаналізі відіграє подвійну роль щзодо становлення розуміння ситуації множинної соціальної ідентичності. По-перше, розщеплення свідомості можна подолати лище завдяки свідомому зверненню до теми Іншого, тобто до комунікативної проблематики. Ця проблематика значною мірою може бути прояснена для суб'єкта завдяки аналізу структур мови як таких, що визначають можливості комунікації. Тут з'ясовується принцииоова розщепленість суб'єкта, яка дає розуміння механізму функціонування множинної соціальної ідентичності. По-друге, звернення до теоретичних можливостей психоаналізу доводить неможливість задовільного сочіального пізнання самого феномену множинної соиіальної ідентичності в рамках психоаналізу, оскільки психоаналіз не виходить за рамки парадигми суб'єкта, а отже не може бути повною мірою переосмисленим на комунікативних засадах. Водночас, концепчія Жака Лакана, розглядаючи взаємодію з іншим у термінах фантазму здійснення бажання, вказує на певні межі самої комунікативної парадигми, яка ніколи не здатна повною мірою подолати розщеплення суб'єктивності, але швидше заохочує $i$ продукує їі. У иьому аспекті сочіальна комунікачія виступає як одна з головних причин появи, відтворення і розвитку множинної соціальної ідентичності. Чим складнімі і більш варіативні засоби соціальної комунікації, тим більшою є потреба у множинній соціальній ідентичності.

Ключові слова: розщеплення свідомості, розщеплення суб'єкта, множинна сочіальна ідентичність, психоаналіз, сочіальне пізнання.

Актуальність проблеми. Одним 3 найважливіших досягнень теорії Зігмунда Фройда з точки зору філософії є виявлення феномену структури свідомості, точніше утвердження тези щодо принципової структурованості свідомості. Згодом у психоаналізі ця теза поступово трансформується у положення щодо розщеплення людської суб’ єктивності як нормального, а не патологічного явища - передусім у працях Жака Лакана. Для соціального пізнання це мало множинні наслідки - як щодо його предмету, методів, так i щодо цілей і засобів їхнього досягнення. Зокрема, саме завдяки концепту розщеплення суб'єктивності стало можливим краще розуміння, яким чином множинна соціальна ідентичність функціонує на рівні свідомості (Boychenko, 
2017). Таким чином, нижче буде здійснено спробу часткової реконструкції концепції психоаналізу щодо розщеплення свідомості та розщеплення суб'єктивності - але не у повному обсязі, а лише під кутом зору того, якою мірою ця концепція створює теоретичне підгрунтя для концепції множинної соціальної ідентичності.

Фройд неодноразово звертається до теми розщеплення свідомості, змістів свідомості, розщеплення Я. Особливо розробленим є останній сюжет, щодо якого у Словнику психоаналізу Жака Лапланша і Жана-Бертрана Понталіса $\epsilon$ спеціальна стаття. Мова у Фройда йде переважно щодо розщеплення Я за ознакою різного типу психічних настанов щодо зовнішньої реальності. У статті «Розщеплення Я» автори цього словника стверджують: «всередині Я співіснують дві психічні настанови щодо зовнішньої реальності, яка суперечить потягам: перша враховує реальність, друга ігнорує їі, висуваючи на перший план бажання. Ці настанови співіснують, не надаючи одна на іншу жодного впливу» (Лапланш, Понталис, 1996).

Фройд у праці «Положення про два принципи психічної діяльності» зазначає: «Як прагне до задоволення Я (Его) може тільки бажати, шукати задоволення і уникати незадоволення, так що прагне до реальності Я (Его) має шукати користі і застрахувати себе від шкоди. Насправді заміна принципу задоволення принципом реальності не означає зовсім усунення принципу задоволення, а тільки підкріплення цього останнього. Миттєве, але сумнівне за своїми наслідками задоволення усувають лише для того, щоб на новому шляху забезпечити собі більш надійне, хоча і відтерміноване» (c. 104). У Фройда при цьому головним механізмом такого заміщення $\epsilon$ дорослішання людини, яке супроводжується розвитком ії̈ психіки: «У той час як «Я» здійснює перетворення 3 «Я», яке прагне до задоволення, в «Я», яке прагне до реальності, сексуальні потяги зазнають низку змін - від початкового аутоеротизму через різні проміжні фази до спрямованої на об'єкт любові, яка слугує функції розмноження» (Фрейд, 1998, с. 106). Тобто від несвідомого потягу до безпосереднього задоволення до все більш свідомого 
потягу до контролю за задоволенням завдяки дистанціюванню від нього і опосередкуванню його досягнення певними, як правило соціальними, діями.

У іншій статті «Я-задоволення - Я-реальність» Лапланш і Понталіс привертають увагу до того, що у праці «Потяги і їхні долі» Фройд розглядає ці два Я не як послідовні стадії, але швидше як співіснуючі: «...у «Потяги і долі потягів» поняття Я-задоволення означає не лише Я, кероване принципом незадоволення-задоволення, але i Я, яке ототожнюється 3 приємним на противагу неприємному. В цьому випадку тут знову-таки протиставені два етапи еволюції Я, тільки цього разу вони визначені змінами меж і змісту Я» (Лапланш, Понталис, 1996). Між іншим, саме у праці «Потяги і їхні долі» Фройд звертає увагу на те, що саме певне роздвоєння Я уможливлює садизм, мазохізм, ексгібіціонізм (Фрейд, 1999, с. 128-130). Дійсно, людина використовує себе у певній якості лише тоді, коли вона фактично має дві свої іпостасі - активну, яка використовує пасивну, і пасивну, яку використовує активна.

Всі ці дії можливі завдяки принциповій неоднорідності людської свідомості, іiі структурованості. Визнання цього факту стало можливим саме завдяки психоаналізу і вирішальним був внесок Фройда. Якщо у філософіï раніше використовували термін «несвідоме», наприклад, у німецькій філософії послідовно спочатку Готфрід Ляйбніц (несвідоме як досвідоме узагальнення нескінченно малих - темних перцепцій (Лейбниц, 1982)), згодом Імануїл Кант (несвідомий апріорний синтез, інтуїція (Кант, 2000)), Фрідріх Шелінг (несвідоме як джерело свободи, як першоджерело всього сущого, яке намагаються передати по-своєму міфологія, мистецтво, релігія (Шеллинг, 1989)), Артур Шопенгауер (несвідома ірраціональна Світова воля (Шопенгауер, 1999)). Вже Едуард фон Гартман у своїй «Філософії несвідомого» спеціально розглядає несвідоме як основу всього сущого, а також чи не вперше прямо стверджує, що несвідоме $\epsilon$ такою ж необхідною і постійно присутньою частиною психіки, як і свідоме (Гартман, 1873). Важливу критику невиправданої самовпевненості філософії свідомості послідовно здійснював Фрідріх Ніцше - починаючи з своєї ранньої праці 
«Народження трагедії», у якій він виявляв два основних начала людської культури - аполонійське та діонісійське (Ницше, 2012). У другій половині 19 століття дослідження функціонування людського мозку та загальний прогрес фізіології показали не лише зв’язок між діяльністю людської свідомості та людською тілесністю, але й виявили емпіричні підстави для дослідження складної структури психіки. Це дало потужний поштовх для розвитку емпіричної психології. Таким чином, як розвиток філософії, так і розвиток природничих наук i психології створили необхідні передумови для схвального сприйняття ідей Фройда щодо структурованості свідомості. Відмінність позиції Фройда полягала у тому, що він не стільки протиставляв несвідоме свідомому, скільки показував їхній взаємозв'язок, взаємозалежність їхнього походження і розвитку. Тому структурованість свідомості виглядала у психоаналізі не стільки як підстава для непримиренного конфлікту, як причина постійних змін у змістах свідомості, а також можливість для наукового обгрунтованого впливу на ці зміни.

Саме тема контролю над перебігом процесів свідомості породжує непрямо питання про психічну норму як засіб здійснення такого контролю. Побічним наслідком вчення про розщеплення свідомості стало вчення про розщеплення особистості, або як його називають у сучасній психології і психіатрії «біполярний розлад» (Goodwin, 2012). Чергування надмірного збудження (яке набуває хворобливої гостроти і неконтрольованості) i надмірної втрати інтересу до подій (аж до важких форм депресії), втрати пам'яті про те, що робив у іншому стані та деякі інші ознаки свідчать про те, що людина не просто не володіє ситуацією щодо своєї розщепленості, але й не помічає самого факту розщепленості, наштовхуючись 3 подивом лише на наслідки цієї ситуації. Втім, якщо ми не говоримо про психічні дисфункції, такі як амнезія, тривалі безпричинні депресивні стани або невиправдану ажитацію, тоді питання про психічну норму стає доволі умовним і виглядає більшою мірою культурно детермінованим, аніж зумовленим проблемами психічного здоров'я. Приклад аналізу політично і культурно штучно 
створених норм, які спричиняли невиправданий соціальний контроль і навіть юридичні санкції подає аналіз французьким структуралістом Мішелем Фуко сфери психічних відхилень (Фуко, 1997).

Важливий внесок у подолання погляду на розщеплення свідомості як на хворобу i небезпечну девіацію здійснив Жак Лакан. Для цього він переосмислив базову пару понять «реальність-задоволення» і значною мірою саме завдяки цьому Фройдову тріаду «Воно-Я-Над-Я» замінив тріадою «Реальне-Уявне-Символічне». Лакан настільки посилює значення структури свідомості для iї адекватного аналізу, що психоаналіз Лакана отримав назву структурного психоаналізу. При цьому, як свідчить російський дослідник Ілля Ільїн, Лакан аналізує структури свідомості передусім через дослідження мови: «Специфіка лаканівського розуміння мовної свідомості перш за все полягає в тому, що вона випливає з його уявлення про структуру людської психіки як сферу складної i суперечливої взаємодії трьох складових: Уявного, Символічного і Реального. Ці «інстанції», «порядки» або «регістри» спочатку трактувалися Лаканом як процес лінгвістичного становлення дитини та лише згодом були переосмислені ним як «перспективи» або «плани», як основні «зміни», в яких людина існує незалежно від свого віку. У найзагальнішому плані Уявне - це той комплекс ілюзорних уявлень, який людина створює сама про себе і який відіграє важливу роль ії психічної захисту, або, вірніше, самозахисту. Символічне, - сфера соціальних i культурних норм і уявлень, які індивід засвоює в основному несвідомо, щоб мати можливість нормально існувати в даному йому суспільстві. Нарешті, Реальне - найбільш проблематична категорія Лакана - це та сфера біологічно породжуваних і психічно сублімованих потреб i імпульсів, які не дані свідомості індивіда хоча би у найменш доступній для нього раціоналізованій формі» (Ильин, 1998, с. 67). Як бачимо, у Лакана Уявне і Символічне займають значно більше місце у свідомому житті людини, аніж це було у Фройда. Однак, i Уявне, i Символічне приходять до людини не разом iз мовою, а ще до мови - через стосунки з матір'ю і батьком. Уявне - це світ 
цілісний і затишний, асоційований 3 матір'ю, тоді як Символічне, асоційоване з батьком, вводить суб’єкта у взаємодію з Іншим. Вимір Символічного формується завдяки так званому «дзеркальному Я» людини, вона навчається взаємодіяти з іншими членами суспільства, звертаючись до того соціального порядку, який представляє батько, і тепер уже у цьому порядку шукає соціальні «відображення», у яких впізнає себе (Lacan, 1966, p. 93-100).

Згідно підходу Лакана, несвідоме сутнісно пов'язане з іншою людиною як Іншим. «Несвідоме - це дискурс Іншого», несвідоме для суб’єкта - це «те місце, виходячи 3 якого йому і може бути поставлено питання про його існування» (Lacan, 1966, p. 549). Найбільш яскраво це питання у психоаналізі постає у аспекті стосунків психоаналітика і його пацієнта: психоаналітик підштовхує пацієнта до аналізу його стосунків з іншими для відновлення (нехай і тимчасової) втраченої цілісності його свідомості, однак найбільшим комунікативним досягненням цієї терапії $€$ не встановлення комунікації пацієнта 3 третіми особами, а встановлення його порозуміння 3 самим психоаналітиком.

За межами цієї реальної взаємодії «психоаналітик-пацієнт», маємо справу лише з символічними розривами у комунікації та символічним же їх подоланням. Ролан Барт чіткіше прив'язує проблему розщеплення Я до соціальної комунікації саме як символічної: «У процесі комунікації «Я» демонструє свою неоднорідність. Наприклад, коли я використовую «Я», то тим самим я посилаюся на самого себе, оскільки стверджую: тут має місце акт, який завжди відбувається заново, навіть якщо він повторюється, акт, зміст якого завжди інший. Однак доходячи до свого адресата, цей знак сприймається моїм співрозмовником як стабільний знак, як породження повного коду, зміст якого $є$ рекурентним. Іншими словами, «Я» того, хто пише «Я», - це не те ж саме «Я», що прочитується тобою» (Barthes, 1972, с. 163). Цю позицію адаптують до Лаканівської тріади вже учні Лакана, зокрема - британський постструктураліст Колін МакКейб. Як зауважує Ільїн, у МакКейба має місце така реконструкція концепції розщепленого суб'єкта 
Лакана: «В результаті кожній окремій сфері стали приписувати свій суб'єкт: Реальному - суб'єкт того, хто говорить, Уявному - суб'єкт висловлювання, Символічному - суб'єкт акту висловлювання. Таким чином, мовний суб'єкт для того, щоб бути реалізованим, неминуче має бути розщепленим, фрагментованим на свої різні іпостасі» (Ильин, 1998, с. 78). Так, на прикладі мови Лакан показує не просто функціональну виправданість, а неминучість розщеплення суб'єкта. Інший британський пост структураліст, також послідовник Лакана Стівен Хіт підкреслює, що саме Символічне створює необхідність такого розщеплення: «Уявне ... є тією послідовністю образів, яка відтворюється суб'єктом, щоб заповнити лакуну; Символічне ж складається $з$ провалів, розривів і їхніх наслідків, що «породжує» суб’єкта в цьому розщепленні» (Heath, 1976, p. 55). МакКейб же зауважує, що Символічне лише позначає той кордон, за межі якого постійно намагається вийти суб'єкт: «...ми суб'єкти, що говорять, постійно коливаємося між Символічним і Уявним, постійно уявляючи, що надаємо вживаним нами словам якийсь повнозначний зміст, і постійно дивуємося, виявляючи, що вони визначаються відносинами, які перебувають поза нашим контролем» (MacCabe, 1985, p. 65). Таким чином, як спільні з Бартом структуралістські витоки теорії Лакана, так і іiі розвиток учнями Лакана показують редукцію соціальної комунікації до іiї сприйняття людиною, образно кажучи у Лакана об’єкт спостереження редукується до множини поглядів на цей об'єкт.

Таким чином, підхід Лакана все ж хибує на певну монологічність: виявляючи множинність суб'єктності всередині особистості, Лакан менше уваги приділяє тому, як це відбивається на реальній взаємодії між різними особистостями. В цьому не просто специфічність позиції Лакана, а загальна тенденція розглядати психоаналіз окремо від теорій комунікації. Водночас, вітчизняна дослідниця Олена Бідюк звертає увагу на недооціненість психоаналізу як можливої базової філософської платформи для створення особливої теорії соціальної комунікації: «Наголосимо, що психоаналіз у дослідженнях не лише українських, а й зарубіжних науковців (Д. Кенері, 
А. Еліот, С. Фрош, М. Монтгомері, М. Бреннан, Г. Данкен та ін.) зводиться, як правило, лише до фройдистських постулатів, а юнгівська теорія не свідомого чи архетипний аналіз беруться до уваги неохоче. От і складається враження, ніби психоаналіз - дослідження патологічних рис, які проявляються у процесі комунікації. Насправді, це не зовсім так, бо ж психоаналіз як метод роботи 3 інформацією передусім має на меті виявлення так званої внутрішньої (прихованої) психічної інформації, що знаходиться поза звичним (відкритим) смисловим полем повідомлення. I необов'язково ця інформація повинна бути патологічною. Інша справа, коли йдеться про психоаналіз, що мислиться у системі комунікації і сам є комунікаційним актом. Його мета - подальше коригування психічних проявів особистості комуніканта» (Бідюк, с. 13-14). Втім, на практиці у цій публікації Бідюк лише дає поверхневу реконструкцію теорії архетипів як юнгіанської реалізації концепції колективного несвідомого. Однак, від колективного як інстанції до комунікації ще треба подолати доволі значний шлях, навіть якщо мова йде про колективне несвідоме. Справа у тому, що колективне є сукупністю індивідуальних проявів, тоді як комунікація створює сферу інтерсуб'єктивного, того, що знаходиться ніби «між» суб'єктами, і уможливлює суб'єктність. Чи дає таку можливість психоаналіз?

Дійсно, у самому психоаналізі, навіть у класичній версії Фройда, знаходимо комунікативні ситуації - наприклад, стосунки садиста і мазохіста, стосунки дітей і батьків (аналізовані зокрема через комплекс Едіпа i, згодом, комплекс Електри). Однак, ці комунікативні ситуації розпадаються на окремі монади тих, хто бере участь у комунікації: вони ніби замикаються кожен у собі, а успішно взаємодіють не стільки завдяки певним адекватним ситуації взаємодії реакціям, а завдяки тому, що заздалегідь розвиваються за шаблонами («садист», «мазохіст», «нарцис» тощо), які вже заздалегідь спроектовані як пазли, що складають осмислену картину. Те ж саме, однак, зустрічаємо у Юнга 3 його вченням про інтровертів і екстравертів та інші психотипи за принципом схильності особи до одного з двох полюсів у ще 
трьох парах: мислення-емоції, інтуїція-відчуття, раціональність-ірраціональність (Юнг, 1998). Комбінація цих чотирьох полюсів дає 16 типів, згідно до яких послідовники Юнга класифікують усіх людей. Така класифікація є дещо більш варіативною, аніж запропонована Фройдом, однак вона теж не враховує творчого характеру соціальної комунікації. Відповідно, мова тут йде не про множинність соціальної ідентичності, а про множину сталих, навіть ригідних у своїй незмінності та запрограмованості соціальних ідентичностей.

Навіть повертаючись до Лакана, деякі дослідники використовують його концепцію без належного врахування принципово важливої для нього концепції розщепленості суб’єкта. На думку вітчизняних дослідників-авторів підручника «Сучасна культурологія», Лакан вказує напрям до розкриття реальної можливості вивчення соціальної комунікації і це - конкретизація стосунків між людьми 3 урахуванням їхньої сексуальності: «Лакан критикував символічний порядок культури i мови, в рамках яких відбувається розподіл символічної влади між «чоловічим» і «жіночим» на користь чоловічого: «чоловіче» отримує статус нормативного суб'єкта, а «жіноче» - варіативного Іншого. Бути Іншим означає належати «жіночому» ряду значень, тобто знаходитися в статусі «підпорядкування» в традиційній культурі. Жінка має або прийняти свій статус Іншого і репрезентувати свою суб'єктивність через істероїдні прояви («випадок Дори», описаний 3. Фройдом); або стати в опозицію до культурних норм, стверджуючи свою суб’єктивність, і тим самим викликати роздратування i звинувачення в «бунті». Таким чином, жінка майже позбавлена вибору, оскільки відмовляючись прийняти існуючий культурний порядок і свій статус Іншого, вона не має власного символічного простору вираження, а іiї суб’єктивність маргіналізується. Сексуальність є однією із сфер культури, яка здатна «стирати» дистанцію між «Я» та Іншим, тому феномен жіночої сексуальності сприймається «травматично» чоловіками. Виникає прагнення заперечення «іншої сексуальності» як засобу затвердити власну позицію, а дискримінація 
жінки в соціокультурних практиках є результатом гендерного («чоловічого») дистанціювання і субординації жіночої інакшості» (Кислюк, 2016, с. 287). Не відкидаючи значимість цієї інтерпретації множинності суб'єктивності, все ж зазначимо, що мова тут йде не про внутрішнє розщеплення суб'єкта на множинні суб'єктивності, а швидше про множинність суб'єктивностей у суспільстві. Однак, як і у психоаналізі Фройда, так і тут, можна припускати, що до певної міри така різна орієнтація на Іншого неминуче готує і самість суб'єкта до визнання можливої власної інакшості.

Таким чином, обидві ці спроби підвести комунікативну основу під психоаналіз б'ють повз ціль. Все ж варто уважніше придивитися до концепції Лакана щодо розщеплення суб'єкта. Чи припускає вона в принципі таку «маніпуляцію» комунікативного обгрунтування? 3 одного боку, розщеплення суб'єкта, згідно Лакану, ніколи не редукується до раз і назавжди визначеної структури свідомості - навіть для окремої особистості. Структури свідомості, за Лаканом, принципово нестійкі, адже вони базуються на непередбачуваному, спонтанному несвідомому. I все ж $є$ сталі певні характеристики цього несвідомого. Його потяг завжди є до певної міри потягом до Іншого. Як зауважує російський дослідник філософії Лакана Мазін: «Отже, бажання здобувають як бажання іншого не тому, що інший володіє ключем до бажаного об'єкту, а тому, що за бажанням якогось об'єкту, чи то предмету, або людини, ховається бажання бути визнаним іншим. Це - бажання бути бажаним. Бажання бажати іншого. Так, вже за бажанням отримати молоко стоїть бажання отримати визнання, любов матері. Це визнання по суті справи підтверджує існування. Бути визнаним значить існувати» (Мазин, 2004, c. 15). Однак, чи маємо ми справу у концепції Лакана дійсно зі справжнім соціальним визнанням, як це хочуть бачити деякі його інтерпретатори? Якщо у ранніх працях Лакана ще можна зустріти таку дослідницьку позицію, то згодом Лакан шукає структуралістське пояснення успішності соціальної комунікації, тобто ï забезпечує не збіг бажань комунікантів, а наявність анонімної смислової структури, представленої у мові, яка і уможливлює 
взаємне визнання. При цьому мова водночас постає і як стіна, яка відгороджує людей одне від одного. На нашу думку, Лакан редукує визнання до його символічних проявів у мові, а мову розглядає як характеристику, яка дає можливість розкрити розщепленість особистості на противагу єдності мислення, а не єдності мовної спільноти, Лакан не виходить за межі суб'єкта у сферу інтерсуб'єктивного, а показує необхідність подолання бажання як принципово нездійсненного, як фантазму. Адже досягнення одного бажання не приносить задоволення, а лише продукує нове бажання, отже бажав суб’єкт не щось конкретне, а саме бажання. Тому уся спрямованість на іншого виявляється у Лакана врешті-решт спрямованістю на себе, погляд набуває дзеркальності. А взаємодія 3 Іншим набуває лише символічного значення: «У людського суб’єкта бажання реалізується в іншому, за допомогою іншого. Саме в іншому, за допомогою іншого іменується бажання. Воно вступає в символічне ставлення я і ти, у стосунок взаємного визнання і трансценденції, в порядок закону, вже готового до того, щоб включити в себе історію кожного індивіда» (Лакан, 1998, с. 235). Варто швидше розглядати розщеплення суб’єкта у Лакана як потяг до комунікації, а не іï обгрунтування, адже сенс комунікації не вичерпується самим лише потягом до неї.

Висновки. Таким чином, концепція розщеплення свідомості у психоаналізі відіграє подвійну роль щодо становлення розуміння ситуації множинної соціальної ідентичності. По-перше, розщеплення свідомості можна подолати лише завдяки свідомому зверненню до теми Іншого, тобто до комунікативної проблематики. Ця проблематика значною мірою може бути прояснена для суб’єкта завдяки аналізу структур мови як таких, що визначають можливості комунікації. Тут з'ясовується принципова розщепле-ність суб'єктності, яка дає розуміння механізму функціонування множинної соціальної ідентичності. По-друге, звернення до теоретичних можливостей психоаналізу доводить неможливість задовільного соціального пізнання самого феномену множинної соціальної ідентичності, оскільки психоаналіз не виходить за рамки 
парадигми суб'єкта, а отже не може бути повною мірою переосмисленим на комунікативних засадах. Водночас, концепція Жака Лакана, розглядаючи взаємодію з іншим у термінах фантазму здійснення бажання вказує на певні межі самої комунікативної парадигми, яка ніколи не здатна повною мірою подолати розщеплення суб’єктивності, але швидше заохочує і продукує іiі. У цьому аспекті соціальна комунікація виступає як одна 3 головних причин появи, відтворення i розвитку множинної соціальної ідентичності. Чим складніші і варіативніші засоби соціальної комунікації, тим більшою є потреба у множинній соціальній ідентичності.

\section{Список використаних джерел}

1. Бідюк О.В. (2009) Психоаналіз у системі комунікативних технологій сучасності. Наукові записки. Серія “Культура і соиіальні комунікаціï”. / за заг. ред. канд. філос. наук, доц. Л.В. Квасюк. Острог: Видавництво Національного університету “Острозька академія”, Вип. 1, с. 13-20.

2. Гартман, Э. (1873) Сущуность мирового процесса, или Философия бессознательного: в 3 вып. / [Соч.] дра философии Эдуарда фон Гартмана; по 2 нем. изд. М.: тип. Грачева и Кㅇ , 1873-1875. Вып. 1.1873, 322 с.

3. Ильин И. П. (1998) Постмодернизм. От истоков до конца столетия. Эволюция научного мифа. М. : Интрада, 255 с.

4. Кант І. (2000) Критика чистого розуму / Пер. з нім. та приміт. І. Бурковського. К.: Юніверс, 504 с.

5. Кислюк К.В., Суковата В. А., Алфьорова 3. І., Титар О. В., Ковальова Г. П. (2016) Сучасна культурологія: навч. посіб. для студ. вищ. навч. закл. / за заг. ред. К. В. Кислюка. К. : Кондор-Видавництво, 2016, $342 \mathrm{c}$.

6. Лакан, Ж. (1998) Работы Фрейда по технике психоанализа (Семинары, Книга I (1953/54)). - М.: Издательство “Гнозис", Издательство “Логос", 432 с.

7. Лапланш Ж., Понталис Ж.-Б. (1996) Словарь по психоанализу / пер. с франц. Н.С. Автономовой. М.: Высшая школа, 623 с.

8. Лейбниц Г.В. (1982) Монадология /пер. с нем. Лейбниц Г.В. Сочинения: В 4 т. Т. 1. М.: Мысль, С. $413-$ 429.

9. Мазин, В.А. (2004) Введение в Лакана. М.: Фонд научных исследований «Прагматика культуры», 67 с.

10. Ницше Ф. (2012) Рождение трагедии из духа музыки /пер. с нем. Ницше Ф. Полн. собр. соч. в 13-ти т. Т. 1/1. М.: Культурная революция, с. 7-143.

11. Фрейд 3. (1999) Влечения и их судьба /пер. с нем. М.В.Вульфа. Фрейд 3. Влечения и их судьба. М.: ЗАО ЭКСМО-Пресс, с. 115-150.

12. Фрейд 3. (1998) Положение о двух принципах психической деятельности /пер. с нем. Фрейд 3. Основные психологические теории в психоанализе. Очерк истории психоанализа: Сборник. СПб.: Алетейя, с. 98-107.

13. Фуко М. (1997) История безумия в классическую эпоху /пер. с фр. И.Стаф. СПб.: Университетская книга, $576 \mathrm{c.}$

14. Шеллинг Ф. (1989) Философские исследования о сущности человеческой свободы.1809. Шеллинг Ф. В. И. Сочинения в 2 m. Т. 2. М.: Мысль, с. 86-158.

15. Шопенгауэр А. (1999) Мир как воля и представление / Пер. с нем. Мн.: ООО "Попурри", 1999, 832 с.

16. Юнг К. Г. (1998) Психологические типы /пер.с нем. С.Лорие, Под общ.ред. В.Зеленского. Минск: ООО «Попурри», 1998, 656 с.

17. Barthes R. (1972) To wright? An intrasitive verb? The structuralists. / Ed. by DeGeorge P., DeGeorge F. Garden City, pp. 115-167.

18. Boychenko M. (2017) Social problems creation and solving in a knowledge society. Research Result. Sociology and Management. T.3, Vol.1, 2017. pp. 58-63.

19. Goodwin, Guy M. (2012). "Bipolar disorder". Medicine. 40 (11): 596-598. doi:10.1016/j.mpmed.2012.08.011

20. Heath S. (1976) Anatomy. Screen. L., Vol. 17, No 4. P. 49-56.

21. Lacan J. (1966) Ecrits. Paris, Seuil, 924 p.

22. MacCabe C. (1985) Theoretical essays. Manchester. VIII. 161 p. 


\section{References}

1. Bidiuk O.V. (2009) Psykhoanaliz u systemi komunikatyvnykh tekhnolohii suchasnosti. Naukovi zapysky. Seriia "Kultura i sotsialni komunikatsii". / za zah. red. kand. filos. nauk, dots. L.V. Kvasiuk. Ostroh: Vydavnytstvo Natsionalnoho universytetu "Ostrozka akademiia", Vyp. 1, s. 13-20.

2. Hartman, Э. (1873) Sushchnost myrovoho protsessa, yly Fylosofyia bessoznatelnoho: v 3 vыp. / [Soch.] d-ra fylosofyy Эduarda fon Hartmana; po 2 nem. yzd. M.: typ. Hracheva у K०, 1873-1875. Vыр. 1.1873, 322 s.

3. Ylyn Y. P. (1998) Postmodernyzm. Ot ystokov do kontsa stoletyia. Эvoliutsyia nauchnoho myfa. M. : Yntrada, $255 \mathrm{~s}$.

4. Kant I. (2000) Krytyka chystoho rozumu / Per. z nim. ta prymit. I. Burkovskoho. K.: Yunivers, 504 s.

5. Kysliuk K.V., Sukovata V. A., Alforova Z. I., Tytar O. V., Kovalova H. P. (2016) Suchasna kulturolohiia: navch. posib. dlia stud. vyshch. navch. zakl. / za zah. red. K. V. Kysliuka. K. : Kondor-Vydavnytstvo, 2016,342 s.

6. Lakan, Zh. (1998) Rabotы Freida po tekhnyke psykhoanalyza (Semynarb, Knyha I (1953/54)). - M.: Yzdatelstvo "Hnozys", Yzdatelstvo "Lohos", 432 s.

7. Laplansh Zh., Pontalys Zh.-B. (1996) Slovar po psykhoanalyzu / per. s frants. N.S. Avtonomovoi. M.: Vыsshaia shkola, $623 \mathrm{~s}$.

8. Leibnyts H.V. (1982) Monadolohyia /per. s nem. Leibnyts H.V. Sochynenyia: V 4 t. T. 1. M.: Mыsl, S. 413429.

9. Mazyn, V.A. (2004) Vvedenye v Lakana. M.: Fond nauchnыkh yssledovanyi «Prahmatyka kulturы», 67 s.

10. Nytsshe F. (2012) Rozhdenye trahedyy yz dukha muzыky /per. s nem. Nytsshe F. Poln. sobr. soch. v 13-ty t. T. 1/1. M.: Kulturnaia revoliutsyia, s. 7-143.

11. Freid Z. (1999) Vlechenyia y ykh sudba /per. s nem. M.V.Vulfa. Freid Z. Vlechenyia y ykh sudba. M.: ZAO ЭKSMO-Press, s. 115-150.

12. Freid Z. (1998) Polozhenye o dvukh pryntsypakh psykhycheskoi deiatelnosty/per. s nem. Freid Z. Osnovnыe psykholohycheskye teoryy v psykhoanalyze. Ocherk ystoryy psykhoanalyza: Sbornyk. SPb.: Aleteiia, s. 98-107.

13. Fuko M. (1997) Ystoryia bezumyia v klassycheskuiu эpokhu /per. s fr. Y.Staf. SPb.: Unyversytetskaia knyha, $576 \mathrm{~s}$.

14. Shellynh F. (1989) Fylosofskye yssledovanyia o sushchnosty chelovecheskoi svobodb.1809. Shellynh F. V. Y. Sochynenyia v 2 t. T. 2. M.: Mыsl, s. 86-158.

15. Shopenhauэr A. (1999) Myr kak volia y predstavlenye / Per. s nem. Mn.: OOO "Popurry", 1999,832 s.

16. Yunh K. Н. (1998) Psykholohycheskye tyры /per.s nem. S.Lorye, Pod obshch.red. V.Zelenskoho. Mynsk: OOO «Popurry», 1998, 656 s.

17. Barthes R. (1972) To wright? An intrasitive verb? The structuralists. / Ed. by DeGeorge P., DeGeorge F. Garden City, pp. 115-167.

18. Boychenko M. (2017) Social problems creation and solving in a knowledge society. Research Result. Sociology and Management. T.3, Vol.1, 2017. pp. 58-63.

19. Goodwin, Guy M. (2012). "Bipolar disorder". Medicine. 40 (11): 596-598. doi:10.1016/j.mpmed.2012.08.011

20. Heath S. (1976) Anatomy. Screen. L., Vol. 17, No 4. P. 49-56.

21. Lacan J. (1966) Ecrits. Paris, Seuil, 924 p.

22. MacCabe S. (1985) Theoretical essays. Manchester. VIII. $161 \mathrm{r}$.

\section{КОНЦЕПЦИЯ РАСЩЕПЛЕНИЯ СОЗНАНИЯ В ПСИХОАНАЛИЗЕ И ПОСЛЕДСТВИЯ ЕЕ ПРИМЕНЕНИЯ ДЛЯ СОЦИАЛЬНОГО ПОЗНАНИЯ}

Шевченко 3.В.

Концепция расщепления сознания в психоанализе играет двойную роль для становления понимания ситуации множественной социальной идентичности. Во-первых, расщепление сознания можно преодолеть только благодаря сознательному обращению к теме Другого, то есть к коммуникативной проблематике. Эта проблематика в значительной мере может быть прояснена для субъекта благодаря анализу структур языка как определяющих возможности коммуникации. Здесь выясняется принципиальная расщепленность субъекта, которая дает понимание механизма функционирования множественной социальной идентичности. Во-вторых, обращение к теоретическим возможностям психоанализа доказывает невозможность удовлетворительного социального познания самого феномена множественной социальной идентичности в рамках психоанализа, поскольку психоанализ не выходит за рамки парадигмы субъекта, а следовательно, не может быть в полной мере переосмысленным на коммуникативных началах. В то же время, концепция Жака Лакана, рассматривая взаимодействие с Другим в 
терминах фантазма осуществления желания, указывает на определенные пределы самой коммуникативной парадигмы, которая никогда не способна в полной мере преодолеть расщепление субъекта, но скорее поощряет и производит ее. В этом аспекте социальная коммуникация выступает как одна из главных причин появления, воспроизводства и развития множественной социальной идентичности. Чем сложнее и вариативнее средства социальной коммуникации, тем больше потребность в множественной социальной идентичности.

Ключевые слова: расщепление сознания, расщепление субъекта, множественная социальная идентичность, психоанализ, социальное познание.

\section{THE CONCEPT OF THE SPLIT OF CONSCIOUSNESS IN PSYCHOANALYSIS AND THE CONSEQUENCES OF ITS APPLICATION FOR SOCIAL COGNITION}

\section{Zoya Shevchenko}

The concept of the split of consciousness in psychoanalysis plays a double role in the formation of an understanding of the situation of multiple social identities. First, the split of consciousness can be overcome only through a conscious approach to the theme of the Other, that is, to a communicative perspective. This problem can be largely explained to the subject by analyzing the structures of the language as those that determine the possibilities of communication. Here it turns out the principle splitting of the subject, which gives an understanding of the mechanism of the functioning of multiple social identities. Secondly, the appeal to the theoretical possibilities of psychoanalysis proves the impossibility of satisfactory social knowledge of the phenomenon of multiple social identity within the framework of psychoanalysis, since psychoanalysis does not go beyond the paradigm of the subject, and therefore can not be fully reinterpreted on communicative principles. At the same time, the concept of Jacques Lacan, considering interaction with another in terms of fantasy of desire, points to certain limits of the most communicative paradigm, which is never able to fully overcome the split of subject, but rather encourages and produces it. In this aspect, social communication acts as one of the main causes of the emergence, reproduction and development of multiple social identities. The more complex and more varied means of social communication are, the greater the need for multiple social identities is.

One of the most important achievements of Sigmund Freud's theory from the point of view of philosophy is the discovery of the phenomenon of the structure of consciousness, or rather the assertion of the thesis on the fundamental structuring of consciousness. Subsequently, in the psychoanalysis, this thesis gradually transforms into a position on the splitting of human subjectivity into a normal, rather than a pathological phenomenon - primarily in the works of Jacques Lacan. For social cognition, this has had multiple consequences - both in relation to its subject, methods, and with regard to the goals and means of achieving them. In particular, thanks to the concept of splitting subjectivity it became possible to better understand how a plural social identity functions at the level of consciousness.

The concept of the split of consciousness in psychoanalysis plays a double role in the formation of an understanding of the situation of multiple social identities. First, the split of consciousness can be overcome only through a conscious approach to the theme of the Other, that is, to a communicative perspective. This problem can be largely explained to the subject by analyzing the structures of the language as those that determine the possibilities of communication. Here it turns out the principle splitting of the subject, which gives an understanding of the mechanism of the functioning of multiple social identities. Secondly, the appeal to the theoretical possibilities of psychoanalysis proves the impossibility of satisfactory social knowledge of the phenomenon of multiple social identity within the framework of psychoanalysis, since psychoanalysis does not go beyond the paradigm of the subject, and therefore can not be fully reinterpreted on communicative principles. At the same time, the 
concept of Lacan, considering interaction with another in terms of fantasy of desire, points to certain limits of the most communicative paradigm, which is never able to fully overcome the split of subject, but rather encourages and produces it. In this aspect, social communication acts as one of the main causes of the emergence, reproduction and development of multiple social identities. The more complex and more varied means of social communication are, the greater the need for multiple social identities is.

The most obvious question of interaction with others in psychoanalysis appears in the aspect of the relationship between the psychoanalyst and his patient: the psychoanalyst pushes the patient to analyze his relationship with others to restore (albeit temporarily) the lost integrity of his consciousness, but the greatest communicative achievement of this therapy is not the establishment of patient communication with third parties, and establishing his agreement with the psychoanalyst himself.

If in Lacan's earlier writings it is still possible to find a research approach oriented on the theme of recognition, further Lacan is looking for a structuralist explanation for the success of social communication, that is, it is ensured not by the coincidence of the wishes of the communicants, but by the presence of an anonymous semantic structure presented in the language that enables mutual recognition. At the same time, the language appears as a wall that separates people from one another. Lacan reduces the recognition to its symbolic manifestations in the language, and considers language as a characteristic that enables to reveal the split of the individual in opposition to the unity of thinking, and not the unity of the language community, Lacan does not go beyond the subject in the sphere of the intersubjectivity, but shows the need to overcome the desire as fundamentally impossible as imagination. After all, the achievement of one desire does not bring pleasure, but only produces a new desire, therefore, the subject wanted not something specific, namely desire. Therefore, all the focus on the other manifests itself in Lacan, eventually focusing on itself, the view becomes mirror. And interaction with the Other acquires a symbolic significance.

Key words: split of consciousness, split of subject, multiple social identity, psychoanalysis, social cognition. 